\title{
Nihonnomizubunka: Harmony Between Water and Humans in Japan
}

\author{
Reny Wiyatasari *
}

Japanese Language and Culture Study Program, Faculty of Humanities, Diponegoro University, Jl Prof Soedarto (Diponegoro University), Semarang, Jawa Tengah, Indonesia.

\begin{abstract}
For the Japanese people who are overflowing with the largest water in the world, water is not just an absolute necessity. It plays a large role in the Japanese lifestyle. The variety of activities of Japanese society that involve the element of water makes Japan a nation with a high level of water culture. This research will discuss the harmony between humans and water in Japan. The data was collected through the library method. The harmony between the two is shown by the important role of water in life for Japanese people, including 1) As a symbol of purification in Japanese people's beliefs, 2) It is beneficial for health and healing of various diseases, 3) As one of the important elements to add to the delicacy of Japanese culinary delights, and 4) As a means of communication in the social life of Japanese society. Meanwhile, with regard to water, Japanese people maintain the sustainability and cleanliness of the water environment by 1) Protecting the forest, 2) Protecting the water environment from pollution, and 3) Water savings.
\end{abstract}

\section{Introduction}

Water is the source of life and key to public health. This can be fulfilled if the water consumed is of good quality. Therefore, improving water quality means improving the quality of life for humans and all creatures whose lives depend on water. For the Japanese people, water has a very important meaning. Japan, in addition to having warm weather and a lot of rain, is also a country with abundant water and forests. On a global scale, the proportion of forests is so high that it can be called a forest state. Thanks to this forest gift, the blessing of water are abundant so that Japan is a nation with a high level of "water culture"[1]. Many Japanese lifestyles that use water have survived until now. As an influence of the Shinto religion, this nation also involves a lot of water in its traditions and culture that have existed since thousands of years ago [2]

The awareness of the Japanese people to protect the water environment cannot be separated from this nation's concern for water problems that occur in various parts of the world, such as water pollution and drought that has hit several countries in the world, lack of fresh water and a decrease in the quality of fresh water on a global scale,

\footnotetext{
${ }^{*}$ Corresponding author : reny.wiyatasari@gmail.com
} 
and which more serious is water pollution which causes water sources to become more polluted. These problems, if left unchecked, will have an impact on health problems and also the sustainability of the next generation [1]. Therefore, even though they are very advanced in the fields of technology and economy, Japanese people are very concerned about environmental cleanliness and water cleanliness.

The dependence of the Japanese people on waters and the caring attitude of the Japanese people towards the sustainability and availability of clean water create harmony between the two. Therefore, in this study, the authors are interested in discussing the harmony between water and humans in Japan as seen from how water is involved as an important component in Japanese culture, as well as the meaning of water itself for the Japanese people. At the same time, it will also explain the concern of the Japanese people in maintaining the availability and sustainability of clean water sources.

Research on the theme of water in Japan has been carried out, including Takeuchi and Tanaka (2020) entitled: Water reuse and recycling in Japan - History, current situation, and future perspectives. Takeuchi and Tanaka's (2020) research which is the Core Research for Evolutional Science and Technology (CREST) project from 2010 to 2015 to introduces the history, current situation, and future perspectives of water reclamation and reuse in Japan. The research is carried out in Japan to develops an energy-efficient water reclamation process by utilizing membrane technology and the ozonation processes. Another research on waters is a study conducted by Ike Iswary Lawanda (2008) entitled: Interpenetration between Materasu Oomikami and the Japanese Environment. In his research, Lawanda explains the relationship between Amaterasu Oomikami (who religiously believed to be the ancestor of the Japanese emperor's ancestors) and the environment in Japanese thought. The interpretive method using a symbolic approach results in the understanding that Amaterasu Oomikami and the environment are a system of relationships in Japanese culture where each other linked through a set of values and actions.

If Takeuchi dan Tanaka (2020) research focuses on the history, current situation, and future perspectives of water reclamation and reuse in Japan, and the research conducted by Lawanda discusses the Amaterasu Omikami in Japanese culture and the sacred implications of Amaterasu Omikami in the Japanese environment, this research focuses on the roles of water in life for Japanese people and Japanese people's efforts to care for and maintain the water environment as a form of their care and gratitude to the aquatic environment.

\section{Method}

This article is written descriptively and analyzed through a qualitative approach. The steps taken include data collection, data reduction, data presentasion, and conclusions [5]. Collecting data using the library method by collecting data from various sources. The data were analyzed using qualitative descriptive methods and described based on studies of Japanese culture as a nation with a high level of water culture that always maintains harmony with nature through its discipline of protecting the environment and its care for nature. 


\section{Results and Discussion}

The harmony between water and Japanese society is shown through the important role of water in life for Japanese people, including the following:

\subsection{As a symbol of purification in Japanese people's belief's}

Water has a very important meaning for followers of the Shinto faith in Japan, namely as a symbol of purification or purification. Shinto belief in the spiritual power of water is reflected in many rituals. One of the important features of Shinto rituals is the symbolic purification ritual performed before approaching a Shinto shrine, for example washing hands and mouth [6]. Religious devotion or pledging one's self to obey religion in Shintoism also focuses rituals on water through purification ceremonies that include immersing oneself in a river [2].

The importance of water as another symbol of purification is that the mystical power of water is believed to be able to transfer one's sins or carelessness to a humanshaped paper statue (hitogata) which then throws it into the river. In the sacred Aoi festival, one of the most interesting things happens when women who embrace the style of Heian period fashion seek purification by rinsing their hands in the pond inside the grounds of Kamigamo-jinja Shrine and Shimogamo Shrine Tokyo and Kyoto are examples of two major cities in Japan that are still alive with scenes of ancient customs that used water effectively. Even Kyoto has used water to maintain thousands of years of tradition and culture [2].

\subsection{It is beneficial for health and healing of various diseases}

It is not only the water that flows from the forests in the mountains to the rivers and into the oceans that gives meaning and plays a role in the culture of the Japanese people. The blessing of water that comes out of the bowels of the earth as a result of volcanic activity, namely hot springs (onsen) has contributed a lot to the Japanese people developing a unique hot spring culture. It is estimated that about 3,000 hot springs are coming out of the bowels of the earth and there are more than 27,000 Japanese-style hot springs built in various locations [7], especially locations with beautiful natural scenery backgrounds, such as mountains, beaches, or trees in the forest.

Soaking in a hot spring bath is a Japanese bathing culture that has existed since thousands of years ago Japanese people like soaking in hot springs because it is believed to provide many benefits for body and soul health. Soaking in hot waters not only warm the body in winter or cool down in the summer, but also is believed to improve blood circulation, provide a relaxing effect on the body and mind, and can even make skin beautiful and prevent aging.

Based on research conducted by Mr. Hayakasa, a medical doctor and professor at Tokyo City University for more than two decades, it is known the benefits obtained by soaking in hot water, including: improving blood circulation, reducing back pain, stiff shoulders, rheumatism, pain. joints, reduce the risk of stroke or heart attack, relieve swelling, increase mental efficiency reduce the likelihood of dementia. The various benefits above are determined based on the mineral content and different water temperatures from one onsen to another [8]. 


\subsection{As one of the important elements to add to the delicacy of Japanese culinary delights}

The topography of Japan tends to make the water soft, which means that nutrients, tastes, and smells are easier to release than hard water. Quality water plays a role in improving the taste. Various traditional Japanese food and beverage preparations rely on water as the key to the delicious taste. The key to this always good water quality is that well water in Japan varies very little throughout the year in temperature and taste, so it can be used for Japanese flagship products, such as saké and tea [2].

In Japanese culinary culture, such as cha-no-yu, and traditional food and drink, water plays an important role. Clean water also plays a role in fostering the tea ceremony (sado). It is said that Japanese food such as buckwheat and tofu is delicious because of the soft taste of the water. The bitter taste and astringency of Japanese teas are also easier to expel with soft water. This helps make the difference in taste more pronounced. It is said that soft water is more effective in extracting the flavor components.

Quality water will also give culinary delights made from fish. Fish in Japan taste delicious because they live in clear water that comes from water sources that are kept clear thanks to the discipline of the Japanese people to plant trees in the forests, as well as the discipline to protect the water environment from pollution [9].

There is also dashi, which is a broth made by infusing various dry foods in water to release the flavor. It's hard to imagine Japanese cuisine without dashi because dashi is the essence of Washoku. The dashi, which is made from soft Japanese water, has a complex taste but is also light and delicious.

Dashi is made by boiling kombu (seaweed) and shavings of katsuo-bushi (bonito fish that have been heated to drying) to make a basic cooking ingredient. Combining kombu and katsuo-bushi gives the broth a denser and richer flavor. Other ingredients that are often used to make dashi are niboshi (small dry sardines) and dried shiitake mushrooms. Dashi is also the base ingredient for suimono (clear soup) and misoshiru (miso soup). After the dashi is made, the ingredients for the broth are added and boiled in it, then seasoned with soy sauce or salt for suimono, miso for miso soup. A stewed dish also starts with dashi, with vegetables and perhaps seafood or meat added afterward, and seasonings are usually added when the simmering process is over [2]

\subsection{As a means of communication in the social life of Japanese society}

To support the Japanese bathing culture, hot springs are managed in the form of two facilities, namely sento and onsen. Sento is the term for a traditional Japanese public bath, while onsen refers to a bath that uses water from hot springs with temperatures higher than 25 degrees Celsius. A simple chat as a form of local culture can be awakened from bathing in a sento or an onsen. Going to a sento or an onsen for some Japanese people is not just for bathing, but is used as an opportunity to establish communication with people they know or don't know.

There is a term in Japan, namely Hadaka no Tsukiai or naked communication which refers not only to the bath itself but also to the way people talk to each other in the onsen. All barriers such as age, nationality, cultural background, in the onsen atmosphere, can all communicate freely. At the bathing place, people soak together in the same pool in a relaxed atmosphere so that communication can be well established [10]. 
Respect for living things makes the Japanese people care about the environment. Many things have been done, both by the government and residents of Japan, to maintain the water supply to be maintained, both in terms of quality and availability. Concern for water is carried out, among others, by:

\subsection{Preserving Forest}

The need for clean water consumption in cities with large occupied populations, such as Tokyo, is enormous. Although with the sophistication of technology Japan is indeed able to provide water supply by building dams, reservoirs, and water reservoirs, this is still considered insufficient. The need for water in the long term certainly needs to be supported by efforts to maintain the availability of water sources, one of which is by preserving forests. On a global scale, the proportion of forests in Japan is indeed very high, and thanks to these forests, the blessings of water are abundant. Therefore, protecting large forest areas and their ecosystems is one of the best ways to support the availability of clean water.

In Japan, love, concern, and empathy for the environment and living things, including trees, have been instilled from an early age, both in schools and through TV programs. Since childhood, children are trained and accustomed to like planting trees, especially in the mountains, so that water sources are maintained and sustainable. The more trees, the better the water quality. Water from the mountains will flow into rivers and then empty into the sea. If river water and sea waters are clear, the fish that live in them will be healthy. If the fish is healthy, it tastes good. So, the more trees planted, the more delicious the taste of the fish in the rivers and the sea. This also applies to vegetables. The healthier the water, the fresher and better the quality of the vegetables [9]

\subsection{Keeping the Water Environment from Pollution}

To see the quality of the environment, namely waters, and air, one of them is indicated by the presence or absence of fireflies. These little insects are like the most reliable messengers to know the clearness of waters and fresh air [9]. Similar to fireflies, fish is also one of the aquatic animals that can be an indicator of whether an aquatic ecosystem is healthy or not. [11] writes that in rivers that are crossed by large bridges in the city of Nagoya, large fish are often kept which are not consumed but are allowed to live freely to maintain the river water ecosystem. Turtles are also allowed to live freely under the bridge.

Japan is a developed country that cares about environmental cleanliness. It is stated that Japan is one of only fifteen or so countries in the world with clean water. Even tap water in Japan is safe for direct consumption [11]. Therefore, anyone who visits Japan will be amazed when they see that the water in the ditches and rivers is so clear that it can be a place to live various types of fish.

River water and sewers in Japan are so clean because of the strict regulations on garbages disposal. Garbage is disposed of based on its category and according to a set schedule. If someone discharges garbage according to the category or schedule, a fine will be imposed. Japan also treats the regulation of dirty and used water (soap) not being put into sewers. Residents are encouraged to use natural soap, which is low in pollutants, and they do not wash and dispose of dirt or household waste in the rivers. Various types of dirty and used water from households will be channelled through special pipes [11]. 


\subsection{Waters Saving}

Japan is located in a part of the world where rainfall is generally high, but often the country also experiences a dry season. Therefore, saving water is a form of wisdom in maintaining water availability. Even though Japan is rich in water resources, its people value the existence of water by always using it effectively. Concern for water in Japan is not just the government's homework. The people also have high awareness and value water so much by using it wisely without wasting it, and this has helped the people develop a good life, and their knowledge promotes harmony with water to this day.

Recently, Japan has been developing advanced water treatment technology to ensure an adequate supply of drinking water for all its residents. Japan also built many dams and reservoirs. This step seems necessary given the natural condition of Japan which consists of many mountains, which causes most of the rainwater to flow directly into the sea. Efforts to maintain water availability in various ways, one of which is making infiltration wells to accommodate rainwater. Soil infiltration or underground columns function as reservoir or regulator column, which regulates water discharge which can accommodate liters of rainwaters. The result is extraordinary savings in clean waters.

\section{Conclusion}

Nature has given a lot, and man owes it to its kindness. So, humans should repay nature's kindness by always caring and loving the natural environment. Although the blessings of water are abundant, it does not make Japanese people forget that protecting and caring for water sources must be done continuously and continuously to maintain balance and harmony between humans and water.

\section{References}

[1] TORIGUE, Hiroyuki. (2012). 水と日本人. Tokyo. Iwanami Shoten, Publisher.

[2] NIPONICA:https://web-japan.org/niponica/niponica15/en/feature/index-3.html.

[3] Haruka Takeuchi, Hiroaki Tanaka. (2020). Water reuse and recycling in Japan History, current situation, and future perspectives. Water Cycle 1, 1-12. www.keaipublishing.com/en/journals/water-cycle/.

[4] Ike Iswary Lawanda. (2008). Interpenetrasi Antara Amaterasu Omikami Dan Lingkungan Jepang. Makara, Sosial Humaniora, Vol. 12, No. 2 : 56-64.

[5] Sutopo. H.B. (2002). Metodologi Penelitian Kualitatif. Surakarta.Sebelas Maret University Press

[6] Rex Shelley, at al. (2012). Culture of The World. JAPAN. New York. Marshall Cavendish Benchmark.

[7] NIPPONIA https://web-japan.org/nipponia/nipponia26/en/travel/travel01.html

[8] https://www.liputan6.com/global/read/4444562/berendam-air-panas-di-onsen-jadirahasia-panjang-umur-dan-sehat-orang-jepang

[9] Soepardjo, Djodjok \& Wawan Setiawan. (1999). Budaya Jepang Masa Kini (Kumpulan Arikel). Surabaya. CV. Bintang. Anggota IKAPI

[10] Harisal. (2019). Potensi Onsen sebagai Representasi Wisata Budaya di Jepang dalam Menarik Wisatawan. Media Bina Ilmiah. Vol. 15, No 10. https://ejurnal.binawakya.or.id/index.php/MBI/article/view/257 i.

[11] Ramli, Murni.. (2018). Menjadi Orang Berkarakter dan Berbudaya di Jepang. Yogyakarta. Manggar Media 